\title{
Determinasi Kebijakan Pemberdayaan Masyarakat di Daerah Kawasan Agropolitan Dalam Program Hulu Hilir Agromaritim Bidang Pertanian
}

\author{
Lukman Hakim ${ }^{1}$, Aloysius Jondar ${ }^{2}$, Khanifatul Khusna ${ }^{3 *}$ \\ ${ }^{1}$ Ilmu Administrasi Negara, Universitas Teknologi Surabaya, Indonesia \\ ${ }^{2}$ Ilmu Administrasi Negara, Universitas Teknologi Surabaya, Indonesia \\ ${ }^{3}$ Ilmu Administrasi Negara, Universitas Jember, Indonesia
}

\begin{abstract}
Jember Regency is one of the largest rice producing centers in East Java and is a rice development area for East Java. Jember Regency has the largest average rice production in East Java, amounting to 915,198 tons. Therefore, rice production in Jember Regency is able to provide the highest contribution to National Production amounting to 1.381. In order to realize farmer empowerment in Jember Regency, the provincial government of East Java has held an agromaritim upstream and downstream agricultural program since 2017. However, this program has experienced bottlenecks in its downstream program. This research uses a qualitative approach. Research location in Jember Regency. Data collection techniques using in-depth interviews, observation and literature study. The data analysis technique in this study was carried out in three stages, namely data reduction, data presentation and drawing conclusions. The results of the data analysis show that there is a determination that causes the program to fail, including the lack of support from the local government as the program provider, the farmers' lack of commitment as program recipients, and the limitations of the GAPOKTAN institution in supporting or supporting the program's operation. These three determinations ultimately hamper the agromaritim upstream downstream program from reaching its point of success.
\end{abstract}

Keywords: empowerment, determination, policy, farmers

\begin{abstract}
Abstrak
Kabupaten Jember adalah salah satu sentra penghasil padi terbesar di Jawa Timur dan menjadi Kawasan pengembangan padi Jawa Timur Kabupaten Jember memiliki rerata Produksi Padi terbesar di Jawa Timur sebesar 915.198 ton. Oleh sebab itu, produksi tanaman padi di Kabupaten Jember mampu memberikan kontribusi tertinggi terhadap Produksi Nasional sebesar 1,381. Guna mewujudkan pemberdayaan petani di Kabupaten Jember, pemerintah provinsi Jawa Timur telah mengadakan program hulu hilir agromaritim bidang pertanian sejak tahun 2017. Namun program ini mengalami kemacetan pada program hilirnya. Penelitian ini menggunakan pendekatan kualitatif. Lokasi penelitian di Kabupaten Jember. Teknik pengumpulan data menggunakan wawancara mendalam, observasi dan studi pustaka. Teknik analisis data dalam penelitian ini dilakukan dalam tiga tahapan yaitu reduksi data, penyajian data dan penarikan kesimpulan. Hasil dari analisis data adalah Terdapat determinasi yang menyebabkan kegagalan program tersebut antara lain kurangnya dukungan pemerintah daerah sebagai pihak pemberi program, kurang komitmennya para petani sebagai penerima program, serta keterbatasan kelembagaan GAPOKTAN dalam mensupport atau mendukung berjalannya program tersebut. Ketiga determinasi tersebut akhirnya menghambat program hulu hilir agromaritim dalam mencapai titik kesuksesannya.
\end{abstract}

Kata Kunci: pemberdayaan, determinasi, kebijakan, petani

*hannifha91@gmail.com

DOI: https://doi.org/10.26618/kjap.v6i3.4124 


\section{PENDAHULUAN}

Tugas pemerintah daerah di era desentralisasi sangat penting dan kompleks. Salah satu peran pemerintah daerah yang sampai saat ini masih menjadi sorotan adalah fungsi pemberdayaan. Berkaitan dengan hal tersebut maka fungsi pemberdayaan tidak hanya menyangkut dari sisi orang yang diperintah melainkan juga pada sisi pemerintah sebagai fasilitator. Tuntutan masyarakat untuk terlibat dalam proses penyusunan kebijakan merupakan wujud pemberdayaan masyarakat sebagai adanya pemerintah daerah yang berdaya. Konsep pemberdayaan masyarakat tidak hanya semata-mata dikaitkan dengan adanya program yang diberikan kepada masyarakat akan tetapi juga dalam bentuk partisipasi masyarakat yang bersifat komprehensif dan berkelanjutan.

Menurut Laily, Ribawanto, and Nurani (2016) pemberdayaan sebagai sebuah proses dan tujuan. Sebagai proses, pemberdayaan adalah serangkaian kegiatan untuk memperkuat kekuasaan atau keberdayaan kelompok lemah dalam masyarakat, termasuk individu-individu yang mengalami masalah kemiskinan. Sedangkan berdasarkan Undang-Undang Republik Indonesia Nomor 19 Tahun 2013 tentang Perlindungan \& Pemberdayaan Petani pada Pasal 1 Ayat 2 tertulis pengertian pemberdayaan petani yang berbunyi "pemberdayaan petani adalah segala upaya untuk meningkatkan kemampuan petani untuk melaksanakan usaha tani yang lebih baik melalui pendidikan dan pelatihan, penyuluhan dan pendampingan, pengembangan sistem dan sarana pemasaran hasil pertanian, konsolidasi dan jaminan luasan lahan pertanian, kemudahan akses ilmu pengetahuan, teknologi dan informasi, serta penguatan kelembagaan petani”. Petani perlu diberikan perlindungan serta pemberdayan supaya petani memiliki kapasitas untuk terus tumbuh dan berkembang menjadi lebih sejahtera.

Pertimbangan fokus penelitian pada pemberdayaan petani dikarenakan beberapa alasan. Salah satu alasan adalah jumlah penduduk miskin di Jawa Timur tercatat 4.419,10 ribu jiwa atau sebesar 11,09 persen dari jumlah penduduk miskin di Indonesia dan persentase penduduk miskin di daerah perdesaan pada September 2019 sebesar 14,16 persen naik menjadi 14,77 persen pada Maret 2020 (Ryo 2020).

Kabupaten Jember menjadi salah satu dari 8 (delapan) kawasan agropolitan Jawa Timur yang masuk dalam kawasan agropolitan Ijen. Konsep Agropolitan menyediakan pelayanan yang lengkap dari kebutuhan pertanian dan kebutuhan sosial masyarakat suatu wilayah sehingga 
menjadi kawasan perdesaan dengan layanan perkotaan. Kabupaten Jember melakukan kajian di beberapa wilayah dalam penerapan kawasan agropolitan sehingga Kabupaten Jember terpilih sebagai salah satu kawasan agropolitan ijen (Dewi 2013).

Agropolitan adalah kota pertanian yang tumbuh dan berkembang karena berjalannya sistem dan usaha agribisnisnya serta mampu melayani, mendorong, menarik dan menghela kegiatan pembangunan pertanian agribisnis diwilayah sekitarnya. Hal ini menunjukkan kemampuan Kabupaten Jember dalam mengelola hasil pertaniannya secara maksimal.

Selain itu, Kabupaten Jember juga menjadi sasaran kawasan tanaman pangan padi di Jawa Timur. Sektor bidang pertanian merupakan sektor unggulan Kabupaten Jember dengan sebagian besar kecamatan memiliki sektor basis pada lapangan usaha pertanian utamanya komoditi tanaman pangan (Widjajanti and Fauzi 2010). Namun sangat disayangkan pada tahun 2019 penurunan produksi padi yang relatif besar terjadi pada Kabupaten Jember dimana penurunan tersebut juga menyebabkan penurunan Total produksi padi di Jawa Timur pada tahun 2019 sekitar 9,58 juta ton kering Gabah Kering Giling (GKG) atau mengalami penurunan sebanyak 622,279 ribu ton $(6,10$ persen) dibandingkan tahun 2018. Namun Kabupaten Jember masih menduduki 10 besar Kabupaten dengan produksi padi terbesar di Jawa Timur (Anonim 2020).

Berdasarkan alasan di atas, guna mewujudkan pemberdayaan petani secara lebih maksimal maka pemerintah provinsi Jawa Timur telah mengadakan program hulu hilir agromaritim bidang pertanian sejak tahun 2017 dibeberapa daerah termasuk Kabupaten Jember. Akan tetapi program ini tidak berjalan secara optimal di Kabupaten Jember. Hal ini berdasarkan hasil evaluasi tahunan yang dilakukan oleh pemprov Jawa Timur yang menunjukkan bahwa Kabupaten Tuban menjadi Kabupaten dengan program hulu hilir agromaritim terbaik se-Jawa Timur dengan segala keterbatasan dan kelebihannya (Safuwan 2018). Kasus ini menunjukkan bahwa belum mampunya petani, pemda dan dinas terkait Kabupaten Jember dalam memaksimalkan program dari pemerintah provinsi.

Satriawan and Oktavianti (2012) dalam penelitiannya mewawancarai beberapa petani di Jawa Timur dengan hasil bahwa terdapat beberapa cara untuk mengatasi pemberdayaan petani miskin melalui beberapa program. Programprogram prioritas yang berhasil disusun sebagai solusi bagi berbagai permasalahan tersebut antara lain: program penciptaan pasar bagi petani, program pembentukan / 
pengaktifan KUT / Gapoktan, program pendampingan KUT/Gapoktan, serta program pengadaan lahan percontohan di masingmasing desa. Keempat program tersebut akan diimplementasikan dalam bentuk kebijakan-kebijakan.

Menurut (Yulhendri and Angraini 2018) dalam penelitiannya menjelaskan bahwa ada 3 (tiga) faktor yang menjadi penyebab tingkat kemiskinan petani yakni pendidikan, kesempatan kerja, budaya kerja, luas lahan dan pasar. Warto (2015) menjelaskan bahwa kemiskinan petani/buruh tani tidak hanya menyangkut keadaan ekonomi, tetapi juga menyangkut aspek sosial dan budaya masyarakat setempat. Upaya penanggulangan kemiskinan petani perdesaan diperlukan suatu strategi, di antaranya adanya keterpaduan pelaksanaan program dari sejumlah pihak berkompeten, serta tidak hanya menjadi tanggung jawab pemerintah daerah, tetapi juga perlu keterlibatan dunia usaha, lembaga swadaya masyarakat (LSM) peduli kemiskinan, dan masyarakat itu sendiri.

Merujuk pada 3 (tiga) hasil penelitian di atas maka program hulu hilir agromaritim bidang pertanian yang melibatkan beberapa stakeholder dan mempertimbangkan faktor penyebab kemiskinan petani telah memenuhi upaya untuk menanggulangi kemiskinan petani melalui proses pemberdayaan. Akan tetapi hal ini berbeda dengan kenyataan dilapangan atas kegagalan program ini. Berdasarkan wawancara awal dengan dinas pertanian dan holtikultura Kabupaten Jember menjelaskan bahwa program ini mengalami hambatan bahkan kemacetan pada proses hilirisasi dan kemungkinan pada tahun 2020 sudah tidak berjalan kembali.

Hasil penelitian Lubis (2015) menunjukkan bahwa faktor yang mempengaruhi keberhasilan program adalah dari segi koordinasi dan komunikasi antara pemerintah dan masyarakat sebagai penerima program. Sedangkan menurut (Siregar and Isnaini 2014) faktor yang mempengaruhi implementasi kebijakan antara lain komunikasi, kemampuan sumber daya, sikap pelaksana, struktur birokrasi, lingkungan serta ukuran dan tujuan kebijakan. Faktor yang menjadi penunjang dari komunikasi, kemampuan sumber daya, sikap pelaksana, struktur birokrasi, lingkungan serta ukuran dan tujuan kebijakan, dan yang menjadi faktor penghambatnya adalah belum adanya sosialisasi kepada masyarakat, rendahnya SDM, kurangnya dukungan pendapatan desa lain, kurangnya respon pelaksana, tidak adanya pembagian tugas tim, kurang berjalannya peran LPMD dan ketidaktepatan sasaran. (Santoso dan Mihrajhusnita 2017) menambahkan bahwa faktor-faktor implementasi kebijakan yang 
mempengaruhi keberhasilan proyek adalah faktor komunikasi; faktor sumber daya; faktor pengalaman perusahaan; dan faktor birokrasi pengguna anggaran. Faktor yang paling berpengaruh terhadap keberhasilan proyek adalah faktor birokrasi pengguna anggaran.

Penelitian ini akan menjelaskan mengenai faktor-faktor penghambat implementasi program hulu hilir agromaritim bidang pertanian di Kabupaten Jember dengan meninjau posisinya sebagai salah satu kawasan agropolitan di Jawa Timur. Keunikan penelitian ini dengan penelitian lainnya adalah adanya keterkaitan antara model pemberdayaan masyarakat dengan faktorfaktor penghambatnya (program pemberdayaan).

Menurut Goggin et al. dalam Purwanto and Sulistyastuti (2015) Keberhasilan implementasi pesan tersebut sangat dipengaruhi oleh 3 hal pokok :

1. Isi kebijakan (the content of policy message), Isi kebijakan meliputi sumber daya, manfaat kebijakan, serta keterlibatan publik;

2. Format kebijkan (the form of the policy message). Format kebijakan terdiri dari kejelasan kebijakan (policy clarity), konsistensi kebijakan (policy consistency), frequency serta penerimaan isi kebijakan (receipt of message);
3. Reputasi aktor (the reputation of the communicators) terdiri dari legitimasi dan kredibilitas aktor - aktor pemerintah daerah.

Berdasarkan latar belakang di atas maka penelitian ini menjelaskan proses program hulu hilir agromaritim bidang pertanian di Kabupaten Jember dan determinasi yang mempengaruhi keberhasilan / kegagalan program hulu hilir agromaritim bidang pertanian di Kabupaten Jember.

\section{METODE PENELITIAN}

Penelitian ini menggunakan metode penelitian kualitatif. Penelitian kualitatif dimaksudkan untuk mengeksplorasi dan memahami makna dari masalah-masalah sosial (Creswell 2010).

Lokasi penelitian adalah Kabupaten Jember sebagai salah satu Kabupaten penerima program hulu hilir agromaritim dan salah satu kawasan agropolitan ijen Jawa Timur. Waktu penelitian akan dilaksanakan pada bulan Januari 2020 sampai selesai.

Key person dalam penelitian ini adalah perwakilan dari pemerintah Kabupaten Jember (informan I) yang selanjutnya dilakukan wawancara dengan perwakilan dinas tanaman pangan dan holtikultura Kabupaten Jember (Informan II) serta ketua GAPOKTAN (Informan III). 
Teknik Pengumpulan Data menggunakan wawancara, observasi dan dokumentasi atau studi pustaka. Wawancara dilakukan dengan masingmasing informan.

Model analisis data dalam penelitian ini menggunakan model interaktif oleh miles dan huberman. Langkah-langkah dalam tahap reduksi antara lain:

1. Meringkaskan data kontak langsung dengan para informan di lokasi penelitian yaitu seluruh stakeholder yang terlibat;

2. Pengkodean, dilakukan dengan melakukan kode pada hasil wawancara dari setiap informan;

3. Membuat catatan pada setiah hasil wawancara dalam bentuk transkip wawancara;

4. Penyimpanan data dari hasil wawancara dan observasi.

Penelitian ini menggunakan triangulasi sumber sebagai teknik pengecekkan kredibilitas (derajat kepercayaan) data. Proses keteralihan dilakukan peneliti dengan uraian rinci dimana peneliti mencocokkan temuantemuan penelitian dengan data yang diperoleh lewat rekaman atau wawancara dan hasil dokumentasi. Selanjutnya untuk mengecek derajat kebergantungan peneliti menggunakan auditing kebergantungan. Langkah-langkah auditing data antara lain pra-entri, penetapan yang dapat diaudit, kesepakatan formal dan penentuan keabsahan data.

\section{HASIL DAN PEMBAHASAN}

\section{Kawasan Agropolitan Ijen}

Teori Agropolitan, lebih memilih pendekatan kebutuhan dasar dan lebih fokus pada pengembangan daerah pedesaan melalui konsep proyek pertanian. Proyek pertanian didasarkan pada ekonomi pertanian yang tumbuh dan berkembang dengan menjalankan sistem dan usaha agribisnis yang dapat melayani dan mendorong kegiatan pengembangan usaha pertanian (agribisnis) di wilayah sekitarnya (Karnaji 2020).

Undang-Undang Republik Indonesia Nomor 26 Tahun 2007 tentang Penataan Ruang menyatakan bahwa yang dimaksud dengan Kawasan Agropolitan adalah kawasan yang terdiri atas satu atau lebih pusat kegiatan pada wilayah perdesaan sebagai sistem produksi pertanian dan pengelolaan sumber daya alam tertentu yang ditunjukkan oleh adanya keterkaitan fungsional dan hierarkhi keruangan satuan sistem permukiman dan agribisnis.

Kawasan agroplitan pada dasarnya adalah kawasan kota pertanian yang tumbuh dan berkembang hingga mampu melayani, mendorong, menarik dan menghela kegiatan agribisnis di wilayah sekitarnya. Pada kawasan agropolitan 
terdapat komoditi unggulan, yang dikembangkan dalam sentral kegiatan agribisnis, serta usaha penunjang lainnya, sehingga mendorong kawasan tersebut berkembang menjadi kawasan agropolitan (Suyatno dalam (Karnaji 2020)).

Cluster atau disebut juga kawasan kewilayahan merupakan dasar sasaran kebijakan pengembangan dalam ranah kewilayahan yang bertujuan untuk melakukan peningkatan pemerataan pertumbuhan ekonomi, sosial, infrastruktur, serta budaya wilayah Provinsi Jawa Timur. Langkah dalam menetapkan kawasan atau clusterisasi dirumuskan menurut arah pembangunan kewilayahan Provinsi Jawa Timur. Pembangunan kewilayahan tersebut menjadi Pusat Agrobisnis terkemuka yang diselaraskan dengan agenda pembangunan, utamanya kawasan strategis agropolitan, kawasan agroindustri, kawasan metropolitan dan kawasan tertinggal. (Asti et al. 2015).

Dalam perencanaan tersebut wilayah Provinsi Jawa Timur dibagi menjadi 7 (tujuh) kawasan pertanian, yakni Agropolitan Madura, Agropolitan Ijen, Agropolitan Bromo Tengger Semeru, Agropolitan Wilis, Agropolitan Metropolitan, Agropolitan Segitiga Emas, dan Agropolitan Kelud. Penetapan kawasan atau cluster pertanian seyogyanya mampu mempertahankan predikat Provinsi
Jawa Timur sebagai lumbung pangan nasional secara periodik. Pembagian wilayah pertanian Agropolitan Ijen meliputi beberapa wilayah kabupaten yaitu kabupaten Jember, Bondowoso, Situbondo, dan Banyuwangi. Agropolitan Ijin memiliki produk unggul dalam proses produksi antara lain padi, jagung, kopi, tembakau dan tebu.

Salah satu produk unggulan Kabupaten Jember selain kopi adalah padi, sehingga Kabupaten Jember menjadi salah satu pilot project dalam program hulu hilir agromaritim bidang pertanian pada kawasan agropolitan ijen. AGROPOLITAN Ijen memiliki fokus dalam pengembangan bisnis perdagangan dan jasa agribisnis.

\section{Program Hulu Hilir Agromaritim Bidang Pertanian}

Kabupaten Jember merupakan sentral produksi padi terbesar di Jawa Timur pada tahun 2016, akan tetapi masih banyak petani padi yang kurang diberdayakan. Berdasarkan alasan tersebut, Kabupaten Jember menjadi salah satu pilot project dari Program hulu hilir agromaritim bidang pertanian yang diselenggarakan oleh Provinsi Jawa Timur (Khusna et al. 2019). Seperti yang telah dijelaskan sebelumnya bahwa program hulu hilir agromaritim bidang pertanian merupakah 
pilot project yang diusung oleh pemerintah Provinsi Jawa Timur dengan tujuan memberdayakan petani melalui kelembagaan. Kelembagaan yang dimaksud adalah GAPOKTAN yang ditunjuk oleh pemerintah daerah terpilih. Program hulu hilir agromaritim adalah program yang sudah dirancang pada akhir tahun 2016 dan diimplementasikan pada awal tahun 2017 dengan beberapa daerah terpilih. Program ini sekarang diterapkan di beberapa kabupaten/kota antara lain Kabupaten Jombang, Kabupaten Jember, Kota Ngawi, Kabupaten Malang, dan Kota Tuban. Program ini mendapat dukungan dari Presiden Joko Widodo, Bank Jatim dan Bank UMKM.

Pemerintah provinsi Jawa Timur telah mengalokasikan dana untuk kredit melalui Bank Jatim dan bank UMKM dengan dibebankan bunga 6\%/tahun. Bantuan kredit tersebut yang selanjutnya digunakan sebagai modal usaha bagi kegiatan setelah/pasca panen oleh sejumlah GAPOKTAN terpilih.

Kredit yang disediakan oleh pihak perbankan dengan sebutan Sarana Produksi Padi (saprodi) memiliki jangka waktu 3 (tiga) tahun. Disisi lain, kredit yang digunakan untuk membeli alat pertaniaan drayer dan alat pembungkus Rice Milling Unit (RMU) diberi jangka waktu 5 (lima) tahun. Terdapat beberapa persyaratan dalam menjalankan program ini yaitu petani yang tergabung dalam GAPOKTAN tidak diperkenankan memakai pupuk subsidi dalam proses bertani, hal dikarenakan supaya petani terpilih tidak ketergantungan terhadap pupuk bersubsidi. Alasan tidak menggunakan pupuk subsidi karena kedepannya pupuk subsidi yang disediakan oleh pemerintah akan ditiadakan atau dihapus. Tujuannya agar para petani mandiri dalam proses bertani. (hasil wawancara dengan Informan II).

Selain itu, dalam proses pelaksanan program tersebut, para petani terpilih disediakan asuransi dari Jasindo yang profitnya ditanggung oleh pemerintah provinsi Jawa Timur. Kegiatan ini bertujuan guna mengantisipasi jikalau terjadi kegagalan panen yang dialami oleh petani. Jika para petani mengalami gagal panen maka sudah jelas petani tersebut tidak bisa membayar kredit yang disediakan oleh Bank Jatim atau Bank UMKM. Ketika hal ini terjadi maka kerugian tersebut sepenuhnya akan diganti oleh Jamkrida.

Kabupaten Jember yang merupakan salah satu kawasan agropolitan ijen dan sebagai salah satu penerima atau pelaksana program telah memilih GAPOKTAN untuk menjalankan program tersebut. GAPOKTAN tersebut adalah Kelompok Tani Mitra Tani Sejati di Desa Sumberjati, Kecamatan Silo, Kabupaten Jember. GAPOKTAN ini beranggota sekitar 600 
orang dan mengerjakan lahan kurang lebih seluas 400 hektar, karena nantinya kelompok tani tersebut akan menjadi pengusaha beras premium.

Kegiatan ini ditandai dengan penyerahan kredit perdana sebesar 9,35 miliyar rupiah sekaligus pada tahun 2018. Penyerahan tersebut diwujudkan dengan penandatangan yang dilakukan antara Ketua bersama Sekretaris GAPOKTAN Mitra Tani Sejati, dengan Asisten Perekonomian dan Pembangunan Pemerintah Provinsi Jatim, Fattah Jasin di Pendapa Wahya Wibawa Graha, pada Rabu 28 Januari 2018.

\section{Kelayakan Program Hulu Hilir Agromaritim}

Kabupaten Jember memiliki potensi untuk di jadikan kawasan Agropolitan dengan berbagai jenis produk pertanian. Berdasarkan hasil wawancara dengan informan I bahwa "kebutuhan pangan Kabupaten Jember itu kurang lebih 300 ribu ton pertahunnya, Nah ... hasil panen padi Kabupaten Jember sendiri mampu menghasilkan 900 ribu ton pertahunnya. Kalau melihat pontensi ini mas, hasil panen padi di Kabupaten Jember mendukung sebagai kawasan agropolitan". Sesuai dengan yang dijelaskan diawal bahwa kawasan agropolitan adalah kawasan dimana suatu daerah pedesaan yang melakukan pengembangan melalui proyek pertanian. Proyek pertanian tersebut dilandaskan atas ekonomi pertanian dengan melaksanakan sistem dan usaha agribisnis yang dapat melayani dan mendorong kegiatan pengembangan usaha pertanian (agribisnis). Definisi tersebut sudah mampu dimiliki oleh Kabupaten Jember. Dengan memiliki kemampuan agribisnis yang baik dari segi kelembagaan ataupun segi individu petani maka akan mampu menciptakan masyakatat petani yang berdaya akan hasil produksinya. Melihat potensi tersebut, pemerintah Provinsi Jawa Timur menganugrahkan Kabupaten Jember sebagai penerima program hulu hilir agromaritim bidang pertanian.

Jika ditinjau dari keadaan alam dan budaya masyarakat sekitar Kabupaten Jember memiliki kelayakan dalam mendukung program hulu hilir agromaritim bidang pertanian. Hal ini disampaikan oleh Informan I bahwa "Kabupaten Jember ini memiliki pusatpusat pertanian yang juga bisa dijadikan sebagai lumbung padi mas dan juga panennya melebihi jumlah padi yang dibutuhkan masyarakat seperti yang saya jelaskan sebelumnya, mangkanya Kabupaten Jember jadi salah satu kawasan agropolitan ijen dan terpilih menjadi pilot project di daerah tapal kuda atau wilayah pendhalungan dalam menjalankan program 
hulu hilir agromaritim bidang pertanian. wilayah-wilayah yang rencananya akan dijadikan wilayah agropolitan berdasarkan hasil kajian sepeti Kecamatan Silo, Kecamatan Balung, Kecamatan Ambulu Serta Kecamatan lain yang mendukung program ini. Tetapi yang terpilih dalam program hulu hilir agromaritim bidang pertanian hanya Kecamatan Silo (wawancara dengan informan II dan informan I).

Berdasarkan penjelasan di atas maka Kabupaten Jember dianggap memiliki kelayakan dalam menerima program tersebut, jika ditinjau dari segi lingkungan pertanian. Jika ditinjau dari sisi pemerintah daerah dan stakeholder yang ikut berpartisipasi dalam program ini, Kabupaten Jember masih memiliki kekurangan dalam proses koordinasi dan kerja sama yang terintegrasi WoG. Menurut (Simatupang 2003) kebijakan pertanian umumnya tergolong kebijakan redistributif atau Political Economic Seeking Transfers (PEST) sehingga merupakan isu ekonomi-politik kontraversial. Sifat yang paradoksal itulah yang menjadi alasan pokok kenapa kebijakan pertanian harus dirancang dengan seksama melalui suatu analisis yang komprehensif.

\section{Determinasi Kegagalan Program Hulu Hilir Agromaritim}

Determinasi kegagalan program atau sering disebut sebagai faktor-faktor yang mempengaruhi kegagalan program hulu hilir agromaritim merupakan sebuah refleksi atau evaluasi terhadap berjalannya program hulu hilir agromaritim bidang pertanian di Kabupaten Jember. Kegiatan atau program yang sudah berjalan hampir 4 (empat) tahun mengalami kemacetan di tengah perjalannya. Oleh sebab itu dijelaskan apa saja determinasi penyebab kegagalan program tersebut.

\section{a. Dukungan Pemerintah Daerah}

Dukungan pemerintah khususnya pemerintah daerah terhadap sektor pertanian diterapkan berdasarkan beberapa instrumen kebijakan yang telah ditetapkan. Komposisi serta besaran dukungan serta proses perubahan perlu dianalisis guna dijadikan perbaikan kebijakan utamanya pembangunan kebijakan pertanian baik dari sisi kelembagaan ataupun individu petani.

Program hulu hilir agromaritim bidang pertanian di Kabupaten Jember masih kurang mendapatkan dukungan secara maksimal dari pemerintah daerah. Hal ini berdasarkan hasil wawancara dengan ketua GAPOKTAN mitra tani sejati bahwa pada pengajuan bantuan yang 
pertama pada tahun 2017 telah dicairkan oleh pemkab Jember. Bantuan tersebut disalurkan kepada petani sebagai pelaksana hulunya dan sudah diterima oleh anggotan GAPOKTAN. Namun untuk bantuan hilirnya sampai saat ini tidak ada kejelasan dari pihak pemerintah daerah setempat. Hal ini juga sesuai dengan hasil wawancara dengan informan I bahwa, pada tahun 2016 pimpinan dinas pertanian Kabupaten Jember melakukan kajian terhadap kawasan agropolitan ijen yang mendapatkan program hulu hilir agromaritim, pada saat itu semua pegawai dinas pertanian Kabupaten Jember sangat antusias terhadap program tersebut. Selanjutnya pada tahun 2017 saya mengajukan rekomendasi kepada bupati namun tidak mendapatkan rekomendasi, pada tahun 2018 instansi terkait mencoba untuk mengajukan rekomendasi lagi namun sekali lagi tidak mendapatkan rekomendasi. Atau bisa jadi proposal yang diajukan tidak disetujui sehingga sampai sekarang program ini sudah tidak berjalan dan sudah tidak ada pertanyaan lagi dari provinsi terhadap keberlanjutannya program hulu hilir agromaritim di daerah agropolitan.

Berdasarkan hasil wawancara di atas maka dapat disimpulkan bahwa faktor dukungan pemerintah dalam pelaksanaan program baik program dari pemerintah daerah maupun program dari pemerintah provinsi sangat menentukan keberhasilan atau kegagalan suatu program. Dukungan dalam bentuk finansial maupun nonfinansial menjadi faktor utama dalam berjalannya suatu program.

\section{b. Komitmen Penerima Program}

Setiap program yang dicanagkan oleh pemerintah tentu akan memiliki penerima manfaat program. Ketika suatu program memiliki tujuan yang sama dengan penerima program maka akan terbentuk suatu komitmen yang kuat unuk mensukseskan program tersebut. Hal ini juga berlaku dalam program hulu hilir agromaritim bidang pertanian Kabupaten Jember. Penerima manfaat dalam program ini adalah petani yang dinaungi dalam GAPOKTAN Mitra Tani Sejati Kecamata Silo. Informan III menjelaskan bahwa petani yang tergabung dalam GAPOKTAN mitra tani sejati telah mendapatkan bantuan atau pinjaman modal sesuai dengan luasan lahan yang diajukan. Pada tahun awal pelaksanaan program jumlah pencairan dana sudah sesuai dengan komitmen dan kontrak di awal. Namun setelah petani melakukan panen padi (beberapa bulan setelah pencairan modal), pihak GAPOKTAN merasa kesulitan untuk menarik uang setoran dari petani yang telah menerima batuan modal tersebut. Keadaan ini dikarenakan hasil panen dari petani yang menerima dana modal dari 
pemerintah lebih memilih menjual hasil panennya kepada kepihak lain. Padahal kesepakatan diawal hasil panen dari petani penerima dana modal harus disetorkan atau dijual kepada GAPOKTAN mitra tani sejati untuk diproses secara langsung menjadi beras premium. Alasan petani penerima dana modal tidak menjual hasil panennya kepada GAPOKTAN karena pihak GAPOKTAN tidak mampu membeli beras hasil panen petani dalam skala besar (tidak mampu menampung gabah hasil panen dari seluruh petani penerima dana modal), sehingga muncul kekhawatiran dari petani akan gabahnya yang tidak laku dan rusak sebelum dibeli.

GAPOKTAN Mitra Tani Sejati tidak mampu menampung seluruh hasil panen gabah petani penerima dana modal karena alat produksi atau gilingan padi yang dimiliki tidak mampu untuk melakukan proses penggilingan padi secara massal atau skala besar. Sehingga GAPOKTAN sendiri tidak mengambil resiko atas permasalah tersebut. Apabila GAPOKTAN memaksa untuk membeli hasil panen gabah petani penerima dana modal, dikhawatirkan GAPOKTAN kana mengalami kerugian. Berdasarkan hasil wawancara tersebut dan deskripsi di atas maka bentuk komitmen antara GAPOKTAN dan petani penerima dana modal perlu untuk ditingkatkan. Selain itu, perlu juga dilakukan analisis situasi dan analisis anggaran bahan mentah agar kerugian yang dikhawatirkan baik oleh GAPOKTAN maupun petani dapat diminimalisir.

\section{c. Keterbatasan Kelembagaan}

Kelembagaan yang dimaksud disini adalah GAPOKTAN Mitra Tani Sejati sebagai penghubung antara petani dengan pemerintah daerah sebagai pemberi program. Terdapat beberapa keterbatasan GAPOKTAN dalam menjalankan program hulu hilir agromaritim bidang pertnian antara lain.

1. Luas lahan sawah seluruh petani diwilayah Kabecamatan Silo adalah seluas $497 \mathrm{Ha}$, dalam satu hari petani dapat melakukan panen kurang lebih 20 s/d 24 Ha. GAPOKTAN Mitra Tani hanya mampu menyerap 2 Ton gabah perhari. Untuk mengolah gabah tersebut menjadi beras GAPOKTAN hanya mampu mengolah sebesar 50\%, sedangkan sisanya di jual ke pihak lain. Seperti yang dijelaskan sebelumnya bahwa GAPOKTAN tidak mampu mengeringkan/menjemur gabah kekurangan lahan lantai jemur dan curah hujan yang tinggi;

2. Berdasarkan hasil wawancara dengan ketua GAPOKTAN Mitra Tani Sejati diperoleh informasi sebagai berikut. RMU (Rice Milling Unit) yang dimiliki GAPOKTAN masih dalam skala 
dengan Kapasitas Normal yaitu $400 \mathrm{Kg}$ /Jam. GAPOKTAN mitra tani sejati telah menyediakan lahan untuk membagung RMU guna menampung hasil panen gabah serta tempat produksi beras premium yang diproduksi sendiri oleh GAPOKTAN. GAPOKTAN mitra tani sejati telah megajukan proposal bantuan untuk menbangun RMU guna mendukung program hulu hilir agromaritim yang menjadi program pemerintah provinsi Jawa Timur. Akan tetapi seperti yang dijelaskan sebelumnya pengajuan ini tidak mendapatkan dukungan dari pemerintah daerah, artinya proposal yang telah diajukan tidak di tandatanggani oleh pihak berwenang, sedangkan lahan sudah disiapkan dan sudah diratankan oleh GAPOKTAN. Lahan tersebut awalnya adalah kebun kopi, dengan komitmen GAPOKTAN maka kebun tersebut diratakan digunakan tempat produksi gabah. Dikarenakan proposal tidak disetujui akhirnya pembagunan ini tidak terlaksana sampai akhir dan lahan tersebut terbengkalai sampai sekarang. Akibatnya program ini tidak berjalan sesaui dengan apa yang telah direncanakan sebelumnya. Program hulu hilir agromaritim hanya berjalan dihulunya sedangkan hilirnya tidak bisa berjalan karena beberapa alasan di atas. Akan disayangkan sekali karena permintaan beras premium hasil produksi GAPOKTAN mitra tani sejati sangat tinggi dan sering kekurangan produk.

\section{KESIMPULAN}

Kawasan Agropolitan Ijen yang dianugrahkan di Kabupaten Jember menjadi salah satu pendukung secara sosial ekonomi dalam proses keberhasilan program hulu hilir agromaritim bidang pertanian. Kekayaan alam yang dimiliki oleh Kabupaten Jember menjadi pertimbangan dalam pemilihan program tersebut. Akan tetapi kelebihan sumber daya alam tersebut yang didukung dengan adanya program pemberdayaan petani melalui program hulu hilir agromaritim bidang pertanian tidaklah cukup untuk menunjang keberhasilan program. Terdapat determinasi yang menyebabkan kegagalan program tersebut antara lain kurangnya dukungan pemerintah daerah sebagai pihak pemberi program, kurang komitmennya para petani sebagai penerima program, serta keterbatasan kelembagaan GAPOKTAN dalam mensupport atau mendukung berjalannya program tersebut. Ketiga determinasi tersebut akhirnya menghambat program hulu hilir agromaritim dalam mencapai titik kesuksesannya. 


\section{REFERENSI}

Anonim. 2020. "Pada 2019, Produksi Padi Jatim 9,58 Juta Ton GKG | Dinas Komunikasi Dan Informatika Provinsi Jawa Timur." Retrieved November 4, 2020

(http://kominfo.jatimprov.go.id/read/u mum/pada-2019-produksi-padi-jatim9-58-juta-ton-gkg).

Asti, Katarina, Noviana Mahasiswa, Anifatul Hanim Dpu, Fajar Wahyu, and Prianto Dpa. 2015. "Penentuan Lokasi Pengembangan Kawasan Agropolitan Dan Penentuan Komoditas Unggulan Di Kabupaten Jember."

Creswell, J. W. 2010. "Research Design: Pendekatan Kualitatif, Kuantitatif, Dan Mixed."

Dewi, Ajeng Novi Ana. 2013. "PENGEMBANGAN KAWASAN AGROPOLITAN AMBULU BALUNG (AMBAL) KABUPATEN JEMBER - PDF Download Gratis." Retrieved November 4, 2020 (https://docplayer.info/38847023-

Pengembangan-kawasan-agropolitanambulu-balung-ambal-kabupatenjember.html).

Karnaji, Karnaji. 2020. "Pengembangan Kawasan Agropolitan Bromo Tengger Semeru." Jurnal Sosiologi Dialektika 13(1):1.

Khusna, Khanifatul, Ruri Fadhilah Kurniati, and Mohammad Muhaimin. 2019. "Pengembangan Model Pemberdayaan Petani Padi Melalui Program Hulu Hilir Agromaritim Bidang Pertanian." Matra Pembaruan 3(2):99-98.

Laily, Sean Fitria Rohmawati, Heru Ribawanto, and Farida Nurani. 2016. "PEMBERDAYAAN PETANI DALAM MENINGKATKAN KETAHANAN PANGAN (Studi Di Desa Betet, Kecamatan Ngronggot, Kabupaten Nganjuk) Sean.” Jurnal Administrasi Publik (JAP), Vol. 2(1):147-53.
Lubis, E. F. 2015. “... Pelaksanaan Program Nasional Pemberdayaan Masyarakat Mandiri Pedesaan (Pnpm Mpd)(Studi Kasus: Kegiatan Simpan Pinjam Perempuan Di Nagari Tanjung ..." PUBLIKA: Jurnal Ilmu Administrasi Publik 1(2):304-17.

Purwanto, Erwan Agus and Dyah Tuti Sulistyastuti. 2015. Implementasi Kebijakan Publik: Konsep Dan Aplikasinya Di Indonesia. Yogyakarta: GAVA MEDIA.

Ryo. 2020. "Maret 2020, BPS Jatim Catat Penduduk Miskin Di Jatim 4.419,10 Ribu Jiwa | Dinas Komunikasi Dan Informatika Provinsi Jawa Timur." Retrieved November 4, 2020 (http://kominfo.jatimprov.go.id/read/u mum/maret-2020-bps-jatim-catatpenduduk-miskin-di-jatim-4-419-10ribu-jiwa).

Safuwan. 2018. “Tuban Terbaik Dalam Program Hulu Hilir Maritim Di Jatim | TIMES Indonesia." Retrieved November 4, 2020 (https://www.timesindonesia.co.id/rea d/news/194361/tuban-terbaik-dalamprogram-hulu-hilir-maritim-di-jatim).

Santoso, Teguh Haris and Isradias Mihrajhusnita. 2017. "FAKTORFAKTOR IMPLEMENTASI KEBIJAKAN YANG MEMPENGARUHI KEBERHASILAN PROYEK BANGUNAN TAHAN GEMPA DI KABUPATEN TEGAL Teguh." Http://E-

Journal.Upstegal.Ac.Id/Index.Php/En g/Issue/View/156 51(1):51.

Satriawan, Bondan and Henny Oktavianti. 2012. "Upaya Pengentasan Kemiskinan Pada Petani 
Menggunakan Model Tindakan

Kolektif Kelembagaan Pertanian."

Jurnal Ekonomi Pembangunan:

Kajian Masalah Ekonomi Dan

Pembangunan 13(1):96.

Simatupang, Pantjar. 2003. "Analisis

Kebijakan: Konsep Dasar Dan

Prosedur Pelaksanaan." Analisis

Kebijakan Pertanian 1(1):1-23.

Siregar, Surya Murni and Isnaini. 2014.

"IMPLEMENTASI KEBIJAKAN

PEMERINTAHAN KABUPATEN

LABUHANBATU DALAM

PEMBERIAN ALOKASI DANA

DESA (ADD) TAHUN 2014 DI

DESA SEI TAMPANG

KECAMATAN BILAH HILIR."

Jurnal Administrasi Publik Public

Administration Journal 2(1):1-22.

Warto. 2015. "Kondisi Kemiskinan Petani Dan Upaya Penanggulangannya." Jurnal Penelitian Kesejahteraan Sosial 14(1):20-29.

Widjajanti, Fefi Nur and Nurul Fathiyah Fauzi. 2010. "KARAKTERISTIK KOMODITAS SUB SEKTOR PERTANIAN DI WILAYAH JALUR LINTAS SELATAN (JLS) KABUPATEN JEMBER [ COMMODITY

CHARACTERISTICS OF AGRICULTURAL SUB- SECTOR IN REGIONAL OF SOUTHERN CROSS LINE (JLS) OF JEMBER REGENCY ]." Agritrop Jurnal IlmuIlmu Pertanian 77-82.

Yulhendri and Rini Angraini. 2018. "ANALISIS FAKTOR-FAKTOR KEMISKINAN MASYARAKAT PETANI DI KECAMATAN LINGGO SARI BAGANTI KABUPATEN PESISIR SELATAN Sumatera Barat." 